\title{
The Role of the State Treasury in the Implementation of the Fiscal Policy to Ensure Microeconomic Stability and Social Security (Research in Vietnam)
}

Phan Huu Nghi, PhD

Le Hung Son, PhD, Associate Professor

The Banking Academy of Vietnam

Abstract

In the period 2011-2016, Vietnam's macroeconomy had not been stable; social security had not witnessed any improvements from the previous period while the state budget was targeted at a large number of objectives such as economic growth, inflation control, assuring security, national defence and social security. During this period, the role of the State Treasury was essential in managing and monitoring cash flow, regulating state budget spending and making it effective for the economy to implement fiscal policy and macroeconomic stability as well as ensuring social security. Accordingly, given the current constraints of fiscal policy, what are the orientations for the State Treasury in performing its operational activities to stabilise the macroeconomy and ensure social security?

Keywords: State Treasury operations; fiscal policy; macroeconomics; social security

JEL Classification: E62, E63, G28, 138

\section{Background}

Vietnam is a developing country and is in the process of finalising its public finance structure financial policy reform, with continuous reference to and learning from both developed and developing countries in the world. It can be most clearly observed in the period of rapid economic growth over a decade from 1997-2007 to the period of recession from 2008-2009 and the economic recovery period from 2010-2016. The complex changes of the global and domestic financial economy, a series of macro policies to stabilise economic growth, control inflation and ensure social security have been launched. However, at present, the process of completing the four key policies in general and the fiscal policy in particular that influence on the socioeconomic situation has many shortcomings due to the widespread involvement of tax authorities, the State Treasury, the State Bank of Vietnam, the Ministry of Finance, the Ministry of Planning and Investment, etc. To implement the fiscal policy effectively, many conditions need to be fulfilled by the related State authorities and the consistent collaboration of the Monetary policy to implement such national financial policy. It is the ultimate goal that all countries and financial systems aim to have effective coordination to achieve.

In the implementation of fiscal policy, the management of state budget revenue and expenditure is to be aligned with the macro-economic objectives such as economic growth, inflation control, unemployment reduction and payment balance maintenance. To implement these objectives for the State Treasury effectively, there should be coordination of authorities in those areas such as finance, tax, treasury, customs and banking. And the State Treasury plays a vital role in the management of cash flow, monitoring the "turning on/off" the valve of the state budget expenditures together with the financial institutions to create effects and efficiency on the economy's implementation of fiscal policy as well as stabilising macro-economy and ensuring social security. However, to promote the role of the State Treasury in implementing the 
Table 1

State budget revenue in the period of 2011-2016 and 2017-2018 estimate

Unit: billion dong

\begin{tabular}{lcccccccc}
\hline \multicolumn{1}{c}{ Year } & 2011 & 2012 & 2013 & 2014 & 2015 & 2016 & $\begin{array}{c}2017 \\
\text { (estimate) }\end{array}$ & $\begin{array}{c}2018 \\
\text { (estimate) }\end{array}$ \\
\hline $\begin{array}{l}\text { Total State } \\
\text { budget revenue } \\
\text { balance }\end{array}$ & 721,804 & 734,883 & 828,348 & 877,697 & 996,870 & $1,107,381$ & $1,212,180$ & $1,319,200$ \\
$\begin{array}{l}\text { Domestic } \\
\text { revenue }\end{array}$ & 443,731 & 477,106 & 513,090 & 593,560 & 740,062 & 886,791 & 990,280 & $1,099,300$ \\
$\begin{array}{l}\text { Revenues from } \\
\text { crude oil }\end{array}$ & 110,205 & 140,106 & 120,436 & 100,082 & 67,510 & 40,186 & 38,300 & 35,900 \\
$\begin{array}{l}\text { State budget } \\
\text { revenue balance } \\
\text { from export, } \\
\text { import }\end{array}$ & 155,765 & 107,404 & 129,385 & 173,005 & 177,293 & 172,026 & 180,000 & 179,000 \\
\hline
\end{tabular}

Source: State Treasury of Vietnam.

policy, it is necessary to analyse and clarify the principle of impact, the role and function of each department in implementing the policy, as well as current restrictions. So, it can be clear about where the State Treasury is standing and what tasks it is supposed to manage to change the fiscal policy towards macro stability and social security.

\section{Status of Implementation of Fiscal Policy by the State Treasury}

With a management system sticking to the target, the development strategy of State Treasury, as well as the mission to collect State budget, achieved a positive outcome with the annual total State budget revenues in the period from 2011-2016 generally completing the assigned budget. Furthermore, most of the budget revenue items were exceeded by 1.51 per cent to 21.31 per cent that contributed to ensuring the budget for capital expenditure, supporting the implementation of economic growth, social, security and defence policies. At the same time, this sets a ground for the government-oriented salary reform. Following that, State budget collection has contributed to ensuring inflation control, economic growth, employment increase and unemployment reduction.

Accompanying with State budget collection, controlling the state budget spending is also one of the most important tasks that determine the economic development and social security stability. State budget spending has generally risen sharply in almost all countries of the world, but the growth rates of state budget expenditures and revenues are usually higher than the rate of economic growth. Following that trend, the increase and decrease in spending on social security will be affected.

In the period from 2011 to 2016, the Government has followed a prudent fiscal policy, tightened its control over public investment, increased control of expenditure to improve the efficiency of using state budget in combination with restructuring the State budget expenditures. Similar to budget revenues, the total state budget expenditures have also increased in the period 2011-2016. In general, the state budget spending in this period was always significant, with the total spending increasing continuously to reach VND 1,295,061 billion in 2016, more than 1.6 times of the budget spending in 2011. The State Treasury system has exercised consistently and strictly its control and payment for budget expenditures (especially expenditures in ODA projects, advance payments to accelerate the progress of unfinished projects), timely met the needs of the units using the budget and ensured strict management of state budget expenditures.

However, the size of government spending is considerably large: the increase in Government spending in 2011-2016 had a positive impact on the economy in the short-term but created longterm uncertainties such as inflation and financial risks due to inefficient spending and difficulties to ensure the effective operation of the financial system. It is noteworthy that investment expen- 
Table 2

State budget expenditures in the period of 2011-2016 and 2017-2018 estimate

Unit: billion dong

\begin{tabular}{|c|c|c|c|c|c|c|c|c|}
\hline Year & 2011 & 2012 & 2013 & 2014 & 2015 & 2016 & $\begin{array}{c}2017 \\
\text { (estimate) }\end{array}$ & $\begin{array}{c}2018 \\
\text { (estimate) }\end{array}$ \\
\hline $\begin{array}{l}\text { Total State budget } \\
\text { revenue balance }\end{array}$ & 787,554 & 978,463 & $1,088,153$ & $1,103,983$ & $1,262,870$ & $1,295,061$ & $1,390,480$ & $1,523,200$ \\
\hline $\begin{array}{l}\text { Capital } \\
\text { expenditure }\end{array}$ & 208,306 & 268,812 & 271.680 & 248,452 & 236,832 & 296,451 & 357,150 & 399,700 \\
\hline $\begin{array}{l}\text { Repayment of } \\
\text { debt and aids }\end{array}$ & 111,943 & 105,838 & 112,055 & 131,940 & 150,000 & 175,784 & 100,200 & 113,818 \\
\hline $\begin{array}{l}\text { Regular } \\
\text { expenditure }\end{array}$ & 467,017 & 603,372 & 704,165 & 723,292 & 790,168 & 822,343 & 896,280 & 940,748 \\
\hline
\end{tabular}

Source: State Treasury of Vietnam. (From 2017, debt repayment includes interest only, not including due principal).

ditures are still spreading out and has failed to focus on the quality and effectiveness of investment projects, causing waste of capital investment. Besides, budget deficits have been used as a tool of fiscal policy to stimulate economic growth over the years, while forecasts and statistics, fiscal policy control as well as the utilisation and management of the State budget are still limited, not tight and effective enough.

The mobilisation of capital also positively affected the fiscal policy in the recent period. Accordingly, from 2011 to 2015, the total mobilised capital from the government bond market was about 907 trillion VND with an average growth rate of 36 per cent per year, accounting for 55 per cent of the domestic capital mobilised capital to the state budget. Outstanding government bond market value increased from VND 202 trillion by the end of 2011 to VND 678 trillion by the end of 2015 (over three times).

The management of the budget fund was effectively implemented as the State Treasury carefully coordinated with the local budget collecting departments to boost the reform of administrative procedures in the field of State budget revenue collection through the expansion of Internet transactions, ATMs, collection via POS (POS).

\section{The State Treasury's Professional Operations Aiming to Stabilise Macro- Economy and Social Security Through the Implementation of Fiscal Policy}

In the prior period, the State Treasury and the Vietnam Government have made a lot of efforts in managing policies and controlling invest- ments in a manner that is conducive to taxation, revenue control as well as capital mobilisation and treasury management. The State Treasury system has played an important role in restructuring the economy, enhancing corporate governance and production capacity, minimising negative impacts of world socio-politics fluctuation. At the same time, this has set the ground for economic development in the period of 2018-2020 as the growth rate of investment has been recovering and increasing in all three sectors of the economy such as public sector, non-public sector and foreign direct investment sector. The impact of these above-mentioned activities on economic growth is quite evident with the average economic growth rate in the period 2011-2017 was estimated at 6.08 per cent, and in 2018, it is expected to reach 6.85 per cent. Although it has not achieved the target set out primarily due to the negative impact of the global economic crisis and the global financial downturn, the export has been rapidly increased, the trade balance has improved and most remarkably, the inflation situation has been adequately controlled.

The CPI dropped from 18.13 per cent in 2011 to 1.84 per cent in 2014 and 0.6 per cent in 2015 the lowest for 14 years. In particular, the price index calculated by each commodity group has also changed significantly according to the objectives of fiscal policy and allocation of the state budget for each sector, mainly for groups of commodity such as food and beverage and related services, medical goods and services. In 2011, inflationary pressure led to fiscal policy tightening. In the 


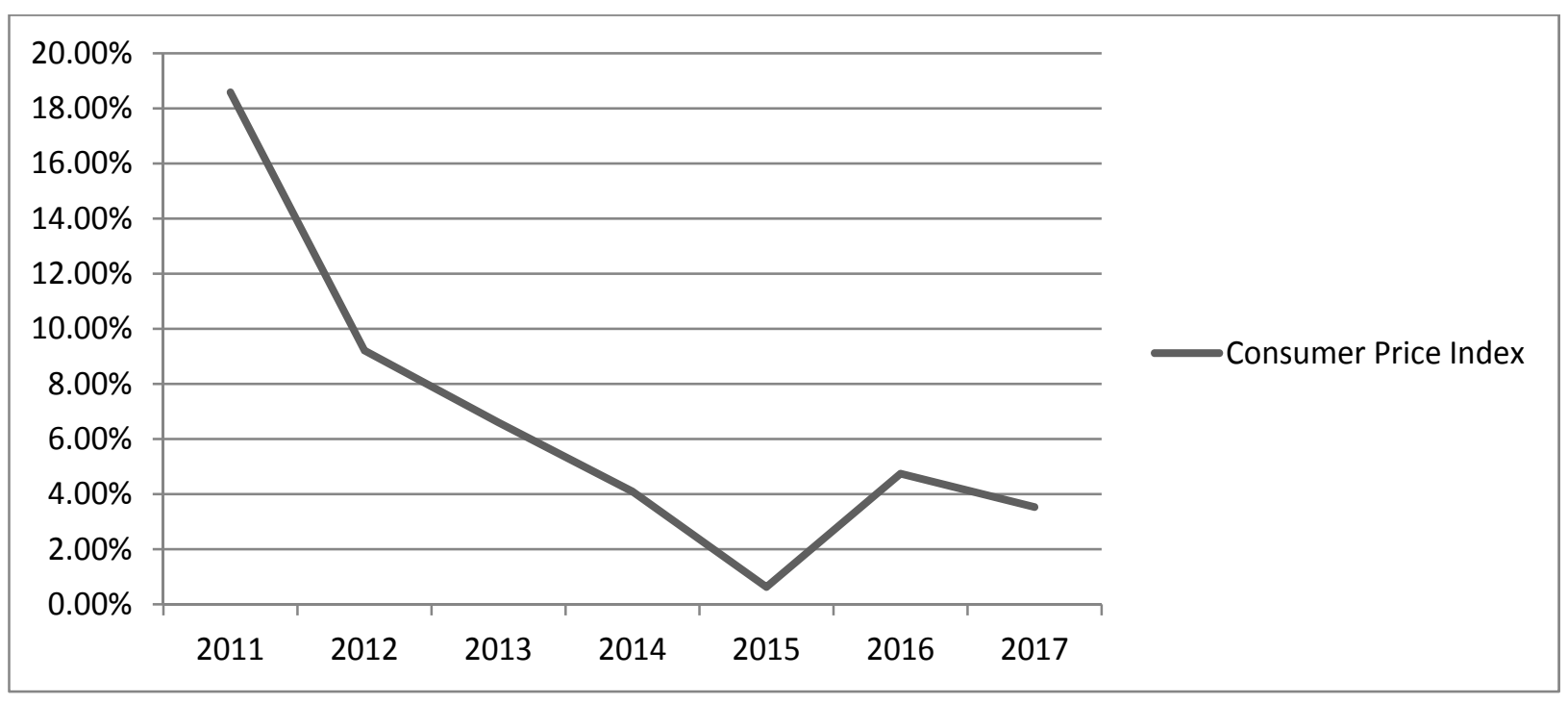

Fig. 1. Monthly consumer price index in the period from 2011 to 2017

Source: General Statistic Office of Vietnam.

period 2012-2017, fiscal policy was stabilised and actively targeted at the stable economic growth combined with inflation control. It could be seen that fiscal policy in this period had accomplished the main objective set by the government, however, due to the negative relationship of macroeconomic objectives, the target had not been thoroughly implemented from time to time.

For the purpose of ensuring social security, the State Treasury has taken specific steps such as controlling state budget revenues and expenditures following closely the decision to reform public pay; achieving social assistance policy with 2.7 million beneficiaries in 2015 equivalent to 3 per cent of the population; increasing state budget expenditures for social insurance annually; adjusting the resources for social welfare by the State Treasury based on the socio-economic policy objectives of each period and the balance of state budget revenue (accounting for 55 per cent of total social welfare expenditure); improving the utility infrastructure and its reciprocal fund from the state budget annually; improving people's ability to approach and use basic social services remarking a highlight in social welfare in Vietnam. However, in the implementation of fiscal policy to ensure social security, the State Treasury's activities also have certain limitations such as failure of fiscal policy in completely directing to social welfare policy; overlap in revenue and expenditure policy and in implementation of programs in the social welfare system; unclear segregation of authority; rigid policies that have not taken into account the characteristics of unofficial sector labour.

\section{Measurement of the Relationship Between Fiscal Policy and Macro- Economic Stability and Social Welfare}

a. Model for assessing the impact of fiscal policy on macro-economic stability

Based on the State Budget's finalised Data from 2000 to 2015 of the State Treasury, the authors have quantified the impact of fiscal policy on macroeconomic stability and social welfare in Vietnam as follows:

To assess the impact of fiscal policy on macroeconomic stability, the authors have examined the elements of fiscal policy among government expenditure items such as capital expenditure, regular expenditure and expenditure for education, health and the part representing the economic growth, i.e. GDP. To measure macroeconomic stability, the authors have used the ARCH-GARCH model to measure the impact of fiscal policy on the variance of GDP growth.

The data used to run the model have been collected from data of Vietnam's macroeconomic variables over the period 2000 to 2015 (Source: The General Statistics Office of Vietnam, ADB and Treasury Vocational Training School). The variables used in the model are described in Table 3.

Variables stop testing

To assess the suitability of the variables before entering the model, the authors have examined the variable stop testing (by Dickey-Fuller unit tests). 
Table 3

The variables used in the ARCH-GARCH model

\begin{tabular}{lll}
\hline \multicolumn{1}{c}{ Variables } & Symbol & Positive/Negative \\
\hline $\begin{array}{l}\text { Dependent Variables } \\
\text { Stability of GDP growth rate } \\
\text { (variance of } \mathrm{R}_{\mathrm{GDP}} \text { ) }\end{array}$ & $\partial_{\mathrm{RGDP}}^{2}$ & \\
$\begin{array}{l}\text { Independent Variables } \\
\text { The growth rate of regular government } \\
\text { expenditure }\end{array}$ & $\mathrm{R}_{\mathrm{CTX}}$ & $(+)$ \\
$\begin{array}{l}\text { The growth rate of capital expenditure } \\
\text { The growth rate of Government expenditure } \\
\text { on Health and Education }\end{array}$ & $\mathrm{R}_{\mathrm{CDT}}$ & $(+)$ \\
\hline
\end{tabular}

Table 4

Result of the unit tests

\begin{tabular}{ccccc}
\hline Variables & C Constant, t Tendency & Lag & T result & Probabilities \\
\hline$R_{G D P}$ & No constant and intercept & 4 & $-4.74^{*}$ & 0.0001 \\
$R_{C T X}$ & No constant and intercept & 4 & $-3.24^{*}$ & 0.0068 \\
$R_{C D T}$ & No constant and intercept & 4 & $-3.43^{*}$ & 0.0018 \\
$R_{C E H}$ & No constant and intercept & 4 & $-3.13^{* *}$ & 0.0034 \\
\hline
\end{tabular}

*: Significant at $1 \%$

**: Significant at $5 \%$

Table 5

Result of co-integrated relations

\begin{tabular}{|c|c|c|c|c|}
\hline \multicolumn{5}{|c|}{ Unlimited Co-integrated level testing (Trace statistics) } \\
\hline Hypothesis & & Trace statistics & 0.05 & \\
\hline $\begin{array}{l}\text { Co-integrated } \\
\text { relation vector }\end{array}$ & Value & Statistic & Limited value & P-value \\
\hline No value* & 0.840236 & 42.28514 & 29.79707 & $0.0011^{*}$ \\
\hline At least 1 value & 0.337864 & 9.272060 & 15.49471 & 0.3408 \\
\hline At least 2 value & 0.097719 & 1.850933 & 3.841466 & 0.1737 \\
\hline
\end{tabular}

* Significant at $1 \%$

Verification of co-integrated relations

Since the proposed variables in the model are stopped (according to the unit test results above), the authors have continued to test the integration of the variables (Table 5).

From the result table, we can see that between GDP growth, regular expenditure and government investment have co-integrated relation.
Distributed-lag model testing

To determine the distributed-lag of the proposed variables in the model, the authors have used the tests to find the most appropriate lag.

The test results have indicated that the appropriate lag for the model is 1 . This lag is relevant to macroeconomic variables in Vietnam. 
Table 6

Result of distributed-lag model

\begin{tabular}{ccccccc}
\hline Lag & LogL & LR & FPE & AIC & SC & HQ \\
\hline 0 & -166.7934 & NA & $31,339.81$ & 18.86593 & 19.01433 & 18.88639 \\
1 & -147.6450 & $29.78645^{*}$ & $10,376.71^{*}$ & $17.73833^{*}$ & $18.33191^{*}$ & $17.82018^{*}$ \\
2 & -140.6737 & 8.520392 & $14,468.43$ & 17.96375 & 19.00251 & 18.10698 \\
3 & -131.9485 & 7.755750 & $20,042.35$ & 17.99428 & 19.47823 & 18.19890 \\
\hline
\end{tabular}

*: Significant at $1 \%$

Table 7

Impact of the increase in regular expenditure and capital expenditure on the stability of GDP growth

\begin{tabular}{cccc}
\hline Variables & Coefficient & Standard deviation & Probability \\
\hline $\mathrm{R}_{\mathrm{CDT}}$ & -0.0051 & 0.0025 & 0.0572 \\
$\mathrm{R}_{\mathrm{CTX}}$ & 0.0352 & 0.0153 & 0.0364 \\
$\mathrm{C}$ & 6.8285 & 0.5428 & 0.0000 \\
$\mathrm{AR}(1)$ & 0.3266 & 0.2186 & 0.1559 \\
$\mathrm{MA}(1)$ & 0.9629 & 0.0286 & 0.0000 \\
$\mathrm{R}^{2}$ & 0.5600 & Durbin-Watson Test & 1.400082 \\
Inverted AR Roots & 0.33 & Inverted MA Roots & -0.96 \\
\hline
\end{tabular}

Estimate the impact of fiscal policy-related factors on the stability of GDP growth

The impact of capital expenditures and regular expenditures on the stability of GDP growth we show in Table 7.

The estimated results in Table 1.5 show that the coefficient $\mathrm{R}^{2}=0.56$, the model is appropriate and such variables as the growth rates of regular and government expenditures can explain $56 \%$ of the variance of GDP growth rate stability. While regular expenditure has a positive effect on the stability of economic growth, capital expenditure has the opposite effect. It may be appropriate for Vietnam, where public investment overwhelms private investment that can cause significant fluctuations in economic growth.

b. A model for assessing the impact of the fiscal policy on social security

To determine the impact of fiscal policy on social security, the authors have also examined the elements of fiscal policy in the Government expenditure items: capital expenditure, regular expenditure and spending on education and medical; and a representative factor of social security which shall be assigned the value of 1 if the percentage of rural households participating in voluntary health insurance is higher than 50 per cent, assigned a value of 0 if the percentage of rural households participating in voluntary health insurance is lower than 50 per cent. Therefore, to evaluate the impact of fiscal policy on social security, the authors have used the Logit model to quantify this relationship.

Model Logit (Maddale, 1984) $\mathrm{p}_{\mathrm{i}}$ is determined by:

$$
\begin{aligned}
& p_{i}=\frac{e^{\beta_{0}+\beta_{1} X_{1 i}}}{1+e^{\beta_{01}+\beta_{1} X_{1 i}}}=\frac{e^{X_{i} \beta}}{1+e^{X_{i} \beta}}=\frac{\exp \left(X_{i} \beta\right)}{1+\exp \left(X_{i} \beta\right)} \\
& X=\left(1, X_{1}\right) ; X_{i}=\left(1, X_{1 i}\right) ; b^{\prime}=\left(b_{0}, b_{1}\right) .
\end{aligned}
$$

In the above model, $\mathrm{p}_{\mathrm{i}}$ is not a linear function of independent variables.

Application of the Logit model in analysing the impact of fiscal policy on social security objectives

The variables included in the model are listed in Table 8.

Since the logit model is nonlinear with independent variables and the dependent variable $\mathrm{Y}$ shall accept the value of only either 0 or 1 , it is not possible to directly apply the least squares (OLS) to estimate the coefficients of the model.

The authors have, therefore used the Maximum Likelihood Estimation method to estimate the coefficients of $\beta i$ of the model. Table 9 summarises the results obtained from the Logit model. 
Table 8

Describe the variables included in the Logit model

\begin{tabular}{|c|c|c|}
\hline Variable name & Symbol & $\begin{array}{l}\text { Expected positive/ } \\
\text { negative }\end{array}$ \\
\hline Dependent variables & ASXH & \\
\hline \multicolumn{3}{|c|}{ Independent variables } \\
\hline The growth rate of regular government expenditure & $\mathrm{R}_{\text {CTX }}$ & $(+)$ \\
\hline The growth rate of capital expenditure & $\mathrm{R}_{\mathrm{CDT}}$ & $(+)$ \\
\hline $\begin{array}{l}\text { The growth rate of Government expenditure on Health and } \\
\text { Education }\end{array}$ & $\mathrm{R}_{\mathrm{CEH}}$ & $(+)$ \\
\hline
\end{tabular}

Table 9

Estimation of Logit model

\begin{tabular}{|c|c|c|c|c|}
\hline Independent variable & $\begin{array}{c}\text { Regression } \\
\text { coefficient }(\beta \mathbf{i})\end{array}$ & $\begin{array}{l}\text { Standard } \\
\text { variance }\end{array}$ & Wald statistic & P-value \\
\hline Intercept & $-30.740^{*}$ & 7.349 & 17.498 & 0.000 \\
\hline $\mathrm{R}_{\text {CEH }}$ & $1.150^{*}$ & 0.362 & 10.076 & 0.002 \\
\hline $\mathrm{R}_{\mathrm{CDT}}$ & $0.531^{* * *}$ & 0.224 & 2.115 & 0.073 \\
\hline $\mathrm{R}_{\text {CTX }}$ & $0.019^{* * *}$ & 0.016 & 2.007 & 0.096 \\
\hline 2-log likelihood & \multicolumn{4}{|c|}{113.206} \\
\hline Cox \& Snell R² & \multicolumn{4}{|c|}{0.525} \\
\hline Nagelkerder $\mathrm{R}^{2}$ & \multicolumn{4}{|c|}{0.657} \\
\hline Homer \& Lemeshow Tess & Chi-square & 10.18 & Sig. & 0.0023 \\
\hline
\end{tabular}

* Significant at $1 \%$

** Significant at 5\%

*** Significant at $10 \%$

The Wald verification and Homer \& Lemeshow verification show that the model is appropriate and the coefficients of the independent variables are statistically significant. The growth rate of regular government expenditure and the growth rate of capital expenditure is significant at 10 per cent, while the growth rate of government spending on health and education is significant at 1 per cent. And whether the coefficients are negative or positive is essential in line with expectations.

In terms of the magnitude of the coefficients, we see that the regression coefficient of the growth rate of government spending on health and education is highest $(1,150)$, which suggests that rural households' participation in voluntary health insurance in the future depends on the government' investment into resolving health and education issues to increase public confidence in the government. The variable that has the least impact on the availability of voluntary health insurance by rural households is the steady increase in government spending, which suggests that excessive spending increases are frequent. It does not necessarily meet the needs of social security of people, especially people in rural areas. Also, this result reflects a problem in Vietnam today that is inefficiency in the regular sources of government expenditure in Vietnam.

\section{Recommendations}

With a view of sticking to the objectives and activities of fiscal policy, the direction of the State 
Treasury system should be adjusted, monitored and supported by the Ministry of Finance, the Ministry of Planning and Investment and relevant agencies in accordance with the following recommendations:

- To review, reform and synchronise documents and administrative procedures in the management of the State budget. In this regard, it is required to continue implementation of E-government in accordance with Resolution No 361/NQ-CP dated 14 October 2015 by the Government on application of information technology in reducing public administrative procedures, enhance the mechanism to operate Tabmis (Treasury and Budget Management Information System) and connection network among the financial agencies; strengthen the efficiency of preparing, allocating and assigning the medium-term state budget in line with the Law on State budget 2015; complete the policy of investment in capital construction, national target programs to ensure the quality, economy and timeliness; supplement legislation to stipulate suitable expenditure level as well as conditions, subjects of expenditures in the locality level.

- To focus on revenue management for fast and timely collection. The management of budget collection requires the enhancement of efficiency through continuous study and revision of taxation and fee policy to boost the revenue collection to 21-23 per cent GDP and the tax and fee collection annual average growth rate by $16-18$ per cent. Achieving this target requires the cooperation of the State Treasury and taxation and customs authorities.

For the State Treasury, finalisation of accounting system on Tabmis to achieve the best performance under the Law on State Budget 2015 should be paid attention. Administrative procedures and forms of the State Treasury should be further clarified to both facilitate the units managing the funds and help the State Treasury units to ensure that the expenditure control is safe, accurate and able to avoids risks for accountants at each State Treasury.

Tax agencies, customs and related departments and agencies should concentrate on directing the implementation of solution to increase revenues; review, adjustment and supplement of the provisions of the tax law must be suitable to the practical situation; control over the transfer of prices of FDI enterprises, significant value-added tax refund amounts in the past years; and promptly handling cases of fraud to avoid losses.

- Improve the quality of control of the State budget expenditures. Accordingly, it is necessary to provide the regulations and limits about advance estimates for the next year and a reasonable balance between revenue and expenditure in some localities. At the same time, it is necessary to limit the expenditures with the change of sources and also those using the list of cash disbursement and encourage annual expenditure saving to control better the cash flow of the units and avoid the risk of loss that may occur.

- Enhance the efficiency of operation of mobilizing state budget capital, proposing basic solutions such as diversifying the maturity of Government bonds, flexible interest rates for each bidding session, coordinating effectively between the State Treasury and the related units in the issuance of Government bonds, which may be deployed through many channels such as direct issuance via the State Treasury, bidding through the Securities Trading Centre, tender through the Transaction Centre of State Bank, underwriting.

- Develop human resources for operational activities of the State Treasury; develop quality personnel of the State Treasury; improve professional qualification, capability and technical knowledge of managers and direct staff. The head should be not only good at professional practice but also have a vision and adaptiveness to every change in the socio-economic progress of the country and the region.

In short, considering the reality of the past few years, it is difficult to analyse the direct and indirect relationship between the roles of the State Treasury and the implementing and stabilising macroeconomics and social security. The fiscal policy alone is not enough to achieve macroeconomic stability. Besides, that there are also other macroeconomic policies aiming to stabilise the macroeconomy with four major indicators in growth, inflation, unemployment and balance of payments and social security policies with the social equality as the ultimate goal. As such, the roles of the State Treasury are not entirely decisive but still play an essential role in contributing to the effectiveness of the fiscal policy and others. 


\title{
References
}

Annual state budget report from 2011 to 2016. The State Treasury of Vietnam.

83/2015/QH13. Law on State Budget promulgated by the National Assembly on 8 December 2015.

56/2006/QH11. Resolution of the National Assembly on the five-year socio-economic development plan 2006-2010.

11/NQ-CP. Resolutions on major measures to control inflation, stabilise the macro economy, and ensure social security.

Chanda A.K., Maddala G. S. (1983). Methods of estimation for models of markets with bounded price variation under rational expectations. Economics Letters, 47, 181-184 [Erratum in Economics Letters, 15 (1984), 195-196]

Engle, Robert F. (1982). Autoregressive Conditional Heteroskedasticity with Estimates of the Variance of United Kingdom Inflation. Econometrica. 50:4, pp. 987-1007.

Maddala, G. S. (1988). Introduction to econometrics. Macmillan Publishing Co., New York. New York, USA.

Maddala, G. S. (1983). Limited Dependent and Qualitative Variables in Econometrics. Cambridge University Press, Cambridge.

Report of the Ministry of Labor, Invalids and Social Affairs 2000-2014.

Роль государственного казначейства в реализации фискальной политики по обеспечению микроэкономической стабильности и социальной защищенности во Вьетнаме

\author{
Фан Ну Нгхи, Ле Хунг Сон
}

\section{Банковская академия Вьетнама}

Аннотация. В статье дан всесторонний анализ деятельности государственного казначейства по стабилизации макроэкономики и развитию социального обеспечения в 2011-2016 гг., когда экономика Вьетнама испытывала серьезные проблемы. В этот период государственная казна играла важнейшую роль в управлении денежными потоками и их контроле, в регулировании расходов госбюджета и обеспечении эффективности бюджетной политики и макроэкономической стабильности. Поскольку средства госбюджета были в основном сосредоточены на решении задач, связанных с экономическим ростом, контролем над инфляцией, обеспечением безопасности и укреплением национальной обороны, деньги на социальное обеспечение направлялись по остаточному принципу и эта сфера не претерпела существенных положительных изменений по сравнению с предыдущим периодом. Рассматривая современную бюджетную политику Вьетнама, характеризуя и оценивая деятельность государственного казначейства по стабилизации макроэкономики и повышению уровня социального обеспечения, авторы отмечают позитивные сдвиги в решении вопросов, связанных с финансированием государственных социальных программ. Ключевые слова: государственное казначейство; фискальная политика; макроэкономика; социальное обеспечение 